\title{
THE APPLICATION OF MEDIATION (SULHC) IN ISLAMIC CRIMINAL LAW
}

\author{
Norjihan Ab Aziz ${ }^{1}$ \\ Nasimah Hussin ${ }^{2}$
}

\begin{abstract}
Dispute resolution through mediation or sulh is encouraged in Islam in almost all disputes. Sulh is not only applicable in civil cases such as matrimonial dispute, custody dispute, transaction dispute and inheritance dispute, but could also be applied in criminal cases as well. In the context of Islamic Criminal Law, șulh is applicable in certain criminal offences of hudūd, qișās and ta'zir particularly when involving the right of individuals. Sulh concerning criminal disputes has been exercised during the period of Prophet Muhammad SAW and legalized in the Quran. There are numerous Qur'anic verses and Ahāaith that allow șulh to be applied in criminal cases. Pakistan has recently implemented the Islamic criminal law, allowing criminal cases to be resolved through sulh. Therefore, this article aims to examine the concept of sulh in criminal cases according to the Quran and Ahädith. This research also analyses how șulh in criminal cases
\end{abstract}

1 Ph.D Candidate, Ahmad Ibrahim Kulliyyah of Laws, International Islamic University Malaysia, Gombak Campus, 50728, Kuala Lumpur, jihan_aziz@ ymail.com

2 Associate Professor, Ahmad Ibrahim Kulliyyah of Laws, International Islamic University Malaysia, Gombak Campus, 50728, Kuala Lumpur, nasimah@iium. edu.my 
is implemented in Pakistan and to determine whether it complies with the Quran and Ahādīth.

Keywords: șulh, qișāṣ, hִudūd, ta'zīr

\section{INTRODUCTION}

In Islamic criminal law, criminal offences are classified into three categories, namely hudūd, qișās and ta 'zīr. Punishment for hudūd and qișāṣ are clearly governed in the Quran and Ahadith of the Prophet SAW except ta'zìr as it is at the discretion of an authority. Islam allows certain offences of hudud, qișās, diyat, and ta 'zìr that have affected the victim personally to be resolved by way of sulh. Islam encourages the offender and the victim of a crime to compromise, to reconcile, and to forgive rather than prolong the dispute to an authority. Through sulh, the offender will not be punished with the original punishment as stipulated in the al-Quran and the Ahādīth, but can be subject to lesser punishment. The authority is not prevented from punishing the offender with $t a$ ' $z \bar{i} r$ if necessary in case the offender and the victim agree to resolve their despite through sulh, in order to educate the public and the offender. Nevertheless, whether or not a criminal case can be resolved through sulh depends on the type of crime committed.

\section{DEFINITION OF ȘULH}

Al-Ṣulh is derived from the Arabic word "șalaha". Literally al-Ṣulh means to 'compromise dispute, or to end dispute among persons.' ${ }^{3}$ Technically, șulh is an agreement between two disputants to reach a settlement or an agreement to compromise between two disputing parties. ${ }^{4}$ The process of sulh may involve the parties of the disputes with or without the assistance of a third party or middleman. ${ }^{5}$

$3 \quad$ Raihanah Azahari, Sulh dalam Kes Kekeluargaan Islam (Kuala Lumpur: Penerbit Universiti Malaya, 2008), 32.

4 Muhammad, I., al-Șulh ka al-Sabab li Inqiḍā'i al-Da 'wā al-Jina 'iyah (Egypt: Dār al-Jamī'ah al-Jadīdah, 2011), 17.

5 Islam, M.Z., 'Provision of Alternative Dispute Resolution Process in Islam,' Journal of Business and Management, 6/3 (2012): 31-36. 


\section{THE LEGALITY OF SִULH IN CRIMINAL CASES ACCORDING TO THE QURAN AND AḤ̂̄DİTH}

The legal basis of șulh in criminal law can be found in numerous verses of Quran and Ahādīth.

\section{The Legality of Șulh in the Quran}

Islam promotes people to make peace and reconciliation when they quarrel, as governed in the Quran which states:

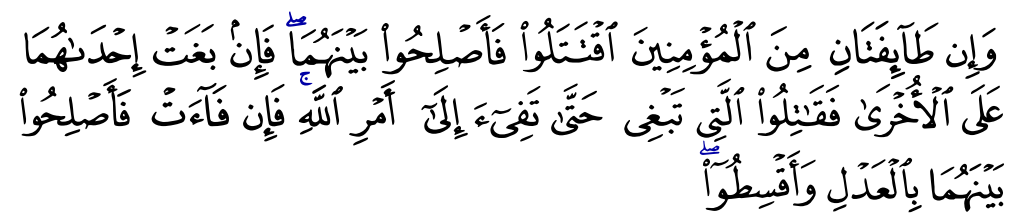

"And if two parties of believers take up arms against each other, make peace between them. If either of them commits aggression against the other, then fight against the aggressor till that party submits to Allah's judgment. When it submits, make peace between them in equity (in accordance with Allah's commandment), and justice (in all dealings)."

(Surah al-Hujurāt, 49: 9)

In another verse, it states that:

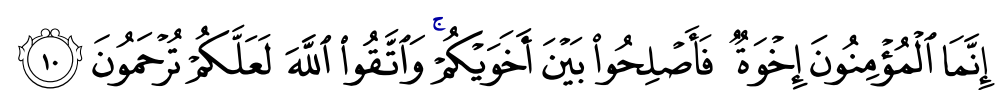

"Truly the believers are brothers. Make peace among your brothers (who are fighting); and remain conscious of Allah, so that you may be shown mercy."

(Surah al-Hujurāt, 49: 10)

This verse indicates that when there are two groups in fighting, make reconciliation between them.

Futhermore, in the Quran, it states that:

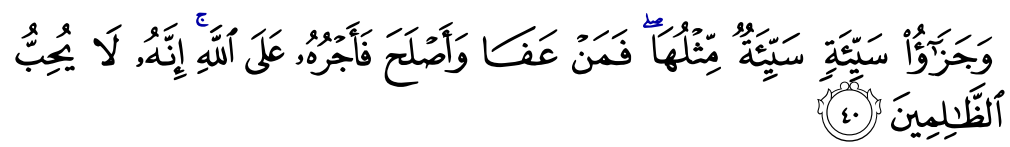


"And (if you wish to requite, then) let evil be rewarded with evil equal thereto; but he who forgives (an evil deed) and seeks reconciliation (with him), his reward rests with Allah (Who will grant him an excellent reward)."

(Surah al-Shūrā: 40)

In this verse, it indicates that Islam allows victims of injury to seek retaliation from the offender. However, if the victim forgives and reconciles with the offender, the victim will be rewarded by Allah.

\section{The Legality of Șulh in Hadith of the Prophet SAW}

In Șahīh Bukhārī it was narrated by Anas that, the Prophet SAW went to see 'Abd Allah bin Ubay by riding a donkey and was accompanied by an Ansari man. When he reached 'Abd Allah bin Ubay, a man from 'Abd Allah's tribe said to the Prophet SAW that the smell of the donkey had harmed him. An Ansari man said to 'Abd Allah, that the smell of the donkey of the Prophet SAW is better than 'Abd Allah's smell. As a result of this remark, a man from 'Abd Allah's tribe became angry and they began fighting with sticks, shoes, and hands. ${ }^{6}$ Subsequently, the following verse was revealed:

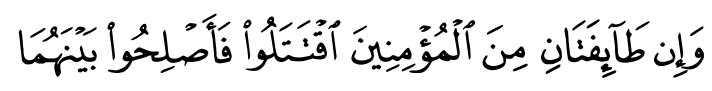

"And if two groups of Believers fall into fighting, then make peace between them."

(Surah al-Ḥujurāt: 9).

Anas al-Rabi also narrated that:

"The daughter of al-Nadr broke the tooth of a girl from al-Rabi. The relatives of al-Rabi requested al-Nadr's relative to accept compensation for the injury and forgive the offender, but they refused. So, they went to the Prophet SAW and he ordered them to retaliate in kind. Anas bin al-Nadr asked the Prophet SAW whether the tooth of al-Rabi would be broken because he does not want to break her teeth. The Prophet SAW replied that Allah ordained retaliation. Later, the relatives of the al-Nadr agreed and forgave her. The Prophet SAW said if an oath has been taken, it must be fulfilled. Anas added, the people agreed and accepted the compensation".?

6 Al-Bukhari, Ṣah̄ịh Bukhārī, Book of Peacemaking, chapter 49, vol. 3, hadith no. 856.

7 Al-Bukhari, Sahih Bukhari, Book of Peacemaking, chapter 49, vol. 3, hadith no. 866. 
This hadith indicates in the case of causing bodily injury that the victim has the right to retaliate or forgive and receive compensation. The parties are bound to the agreement if they resolve the dispute through șulh.

There was a hadith narrated by Wa'il ibn Hujr where a man who committed murder was brought to the Prophet SAW. The Prophet SAW called the heirs of the victim and asked whether they forgave the murderer. The heirs refused to forgive. The Prophet SAW asked whether they would like to accept bloodmoney. The heirs refused to accept the blood-money. Then the Prophet SAW asked whether he wants to kill the murderer. The heirs replies yes. The Prophet SAW asked the heir to take the murderer. After repeating all this a fourth time, the Prophet SAW said:

"If you forgive him, he will bear the burden of his own sin and the sin of the victim. The heir then forgave him" 8

This hadith is about the right of the heirs of the victim of murder. It can be seen that at first the heirs of the victim refused to forgive and take compensation. Even though the Prophet SAW repeated the questions four times the answers given by the heirs are the same until the Prophet SAW said that if the heir forgave the murderer, the murderer will bear the sin of himself and the victim. Only then did the heirs forgive the criminal. This hadith indicates that the Prophet SAW had interfered and tried to reconcile the victim's heir and the murderer by ask the heir to forgive the murderer and offer compensation to the victim.

There is limitation of the application of sulh based on hadith of the Prophet SAW as reported by 'Abd Allah, the son of Amr bin 'Awf that:

"I heard Allah's Messenger saying: 'Compromise is permissible among the Muslims, except the compromise that makes the lawful as unlawful or makes the unlawful as lawful" 9

'Umar Ibn al-Khatțab also mentioned in his letter of judgement to Abū Mūṣā al-Ash'arī "Compromise is permissible between the people except a compromise which would make licit (halāl) which is illicit (harām) or make illicit (harām) which is licit (halāl)". ${ }^{10}$

\footnotetext{
8 Abū Dāwūd, Sunan Abū Dāwūd, Kitab al-Hudūd, vol. 5, hadith no. 4484.

9 Ibn Majah, Sunan Ibn Majah, Book 13, Chapter on Rulings, hadith no. 2353.

10 Hashim Mehat, Malaysian Law \& Islamic Law on Sentencing (University of Michigan: International Law Book Services, 1991), 119.
} 


\section{RIGHT OF ALLAH AND RIGHT OF INDIVIDUALS IN CRIMINAL OFFENCES}

In Islam, rights can be categorised into the rights of Allah and the rights of individuals. The rights of Allah SWT (haqq al-Allah) are an obligation to Allah SWT and corresponds to public interest. The violation of rights will cause liabilities in this world and the hereafter. The rights of Allah SWT are enforced by the state and do not require complaint from the victim ${ }^{11}$ which may include rituals and worship.

The rights of individuals ( $h a q q a l$ - 'ibajd) are for his own interest or for the benefit of others. For instance, commercial rights, contractual rights, political rights, and social rights. Nevertheless, there can be a combination between the rights of Allah SWT and the rights of the individual, but the former prevails or the right of individual prevails. For example, in case of suicide and wasting of property, since both involve rights of Allah and individuals, the rights of Allah is dominant. The right of individuals can be dominant if they (the victim or the heirs) suffers more detriment. ${ }^{12}$

Offences under the Islamic criminal law consist of hudūd, qiṣaș and ta 'zìr. Literally, hudūd means 'limit'. Hudūd is a punishment which is fixed by Allah SWT to fulfil His rights. The punishment cannot be increased, decreased, or waived if the matter has been brought to the ruler because it is imposed for the sake of public interest. Hudüd consist of adultery, false accusations, theft, robbery, drinking wine and apostasy. Hudiud is considered as a crime against Allah SWT as it involves His rights. ${ }^{13}$ However, some offences such as robbery, theft, and false accusations involve both the rights of Allah SWT and the rights of individuals.

Qiṣās means to punish the offender in the same manner as he causes hurt to the victim. Qișās is an offence related to murder and causing bodily injury which affects the victim personally. This offence that infringes the rights of the individual as well as the rights of Allah SWT but the rights of the individual dominate in this respect. Punishment of qișās is fixed by the law of retaliation or diyat (blood money), but can be remitted by the victim and the victim's heirs. ${ }^{14}$

11 Hussain, S.S., Islam and Human Rights (Selangor: Budaya Ilmu, 1991), 8.

12 Mohammad Tahir Haji Mohammad, Rights and Duties in Shari'ah and Common Law (Selangor: Ilmiah Publishers, 2003), 268-271.

13 Muhammad Bakar Ismail, al-Fiqh al-Wadhih: Fiqh Lengkap, trans. M. Yusuf Sinaga et al., vol. 2 (Selangor: Jasmine Enterprise, 2008), 279.

14 Shabbir, M., Outlines of Criminal Law and Justice in Islam (United Kingdom: Edward Elgar Publishing, 2013), 27. 
Ta 'zìr offences are those which are do not fall under the category of hudu or qișās. It is at the discretion of the authority to punish the offender of a $t a$ ' $z \bar{\imath} r$ offence. ${ }^{15} \mathrm{Ta}$ ' $z \bar{r} r$ offences consist of those which violate the rights of Allah and the rights of individuals. Violating the rights of Allah, such as taking riba, breach of trust, and false testimony also includes the violation of the rights of an individual such as defamation and cheating. Punishment of $t a$ ' $z \bar{v} r$ offences consists of admonition, fine, the death penalty, imprisonment, and caning. ${ }^{16}$

In short, if the offence has infringed the rights of Allah SWT the state has to punish the offender, but if the rights of individuals have been violated, the offender shall be liable for restitution or must compensate the victim. The punishment for violating of the rights of Allah SWT is specified in the Quran and Ahạdīth and the state shall punish accordingly.

\section{ȘULH IN ISLAMIC CRIMINAL LAW}

\section{1. Șulh in Hudūd}

There are different views of Muslim scholars on the application of sulh in $h u d \bar{u} d$. Imam Abū Hanifa restricts the application of șulh in hudūd. He opined

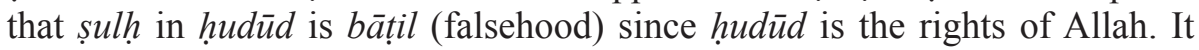
cannot be reconciled, compromised and released without hudiud if the matter has been brought to the authority. However, Imam Abū Hanifa and other Muslim scholars agree that the victim and the offender may resolve offences of false accusation, theft and robbery through sulh if the cases are not brought to the court. ${ }^{17}$

\section{a) Șulh in False Accusation (Qadhaf)}

False accusation (qadhaf) is an offence when any person accused someone falsely of committing fornication and challenging the legitimacy of a child. ${ }^{18}$ A person will be liable and punished for false accusations if he has accused

15 Anwarullah, The Criminal Law of Islam (Kuala Lumpur: A.S. Noordeen, 2008), 27.

16 Al-Zuhaili, W., Fiqh \& Perundangan Islam, trans. Ahmad Shahbari Salamon, vol. 6 (Kuala Lumpur: Dewan Bahasa dan Pustaka, 2006), 208.

17 Mahmood, T., et al., Criminal Law in Islam and the Muslim World: A Comparative Perspective (New Delhi: Institute of Objective Studies, 1996), 62.

18 Shabbir, M., Outlines of Criminal Law and Justice in Islam, 155. 
someone of committing adultery, but fails to produce four witnesses to support the allegation. The punishment for false accusations is stated in the Quran ${ }^{19}$ and comprises of flogging with eighty stripes, and forever rejecting that the person's testimony in court.

Imam Shāfi ‘ $\overline{1}$ and Imam Ahmad agreed that the offence of false accusation is considered as a violation of the rights of Allah as well as rights of the individual. Imam Shāfi' $\overline{1}$, Imam Mālik and Imam Hanbali agreed that if the victim intends to lodge a complaint against the accused and bring the case before the court, if the accused is found guilty, they may be punished with hadd punishment. Otherwise, if the victim does not wish to lodge a complaint against the accused and has forgiven them, the hadd punishment will not be imposed. ${ }^{20}$

\section{b) Șulh in Theft (Sariqa)}

Sulh is encouraged in theft as the offence also involves the rights of individuals. Literally, theft (sariqa) is 'intentionally taking away another's movable property in secret.' ${ }^{21}$ Technically, it means taking away the property from others custody in secret for which the amount is not less than ten dirhms. ${ }^{22}$ The punishment for theft is amputation of the hands of the offender. ${ }^{23}$

There is a hadith where Safwan ibn Umayya's cloak was stolen from at the time he slept at a mosque. The Prophet SAW ordered the thief's hand be cut off, but Safwan said that he did not intend to punish the thief and he wanted to donate the cloak to the thief. Then, the Prophet SAW asked why Safwan did not do this before the matter was brought to him. ${ }^{24}$

This hadith indicates that theft is allowed to be resolved through șulh before the matter is brought to the judge. Hudu $d$ can also be waived if the victim is willing to give the stolen item to the offender as a gift. ${ }^{25}$ If the stolen property

\footnotetext{
Surah al-Nūr: 4-5.

20 Shabbir, M., Outlines of Criminal Law and Justice in Islam, 172-173.

21 Shabbir, M., Outlines of Criminal Law and Justice in Islam, 127.

22 Marghinani, S.B., The Hedaya: Commentary on the Islamic Laws, trans. Charles Hamilton (New Delhi: Kitab Bhavan, 1985), 205.

23 Surah al-Mā'idah, 5: 38.

24 Al-Muwatta of Imam Malik Ibn Anas, Book 41, The First Formulation of Islamic Law, trans. Aisha Abdurrahman Bewley (USA: Routledge, 2010), 350.

25 Nasimah Hussin, 'Mediation in Islamic Criminal Law', in Mediation in Malaysia: the Law and Practice, 355.
} 
is returned to the owner before the victim takes legal action, the allegation is withdrawn and the accused will not be punished. However, if the stolen property is returned after the criminal proceeding begins, regardless of whether the it was property returned before or after trial, hudüd will be imposed upon the offender. ${ }^{26}$

\section{c) Șulh in Robbery (hirabah)}

Sulh is also applicable in robbery. Robbery (hirābah) is to take away property from the custody of another person by threatening or using force. ${ }^{27}$ Hirābah is considered as an offence against an individual and an offence of waging war against Allah and the Prophet SAW through the use of arms. ${ }^{28}$

The punishment of robbery as mentioned in the Quran ${ }^{29}$ is (1) death if homicide is caused by the act of robbery, (2) amputation for the first offence and if the act does not cause death to the victim, (3) crucifixion if the offender commits homicide and robbery, and (4) banishment if the offender did not rob nor kill the victim.

The offender can be exempted from hudüd of robbery if he or she repents before arrest. This is based on the Quran:

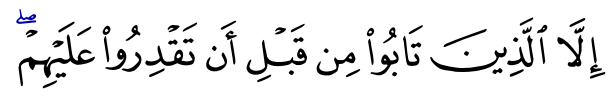

"Except those who repent before you overpower them..."

(Surah al-Mā'idah, 5: 34)

Though the repentance before arrest withdraws hudūd, the offender still carries liability. If the act caused death to the victim, the offender is responsible to the heirs as an act of qișass. The heirs of the victim have the option to either demand qișas or forgive the offender and claim compensation. ${ }^{30}$ If the offender has taken property, the property must be returned to the owner if the offender knows the owner. If the owner is not known, the property must be given to Bayt $a l-M \bar{a} l$. However, if the property is no longer with the offender, the offender must pay the value of the stolen item to the owner.

\footnotetext{
26 Al-Zuhaili, W., Fiqh \& Perundangan Islam, 115.

27 Anwarullah, The Criminal Law of Islam, 190.

28 Muhammad Shabbir, Outlines of Criminal Law and Justice in Islam, 184-191.

29 Surah al-Mā'idah, 5: 33.

30 Nasimah Hussin, 'Mediation in Islamic Criminal Law', in Mediation in Malaysia: The Law and Practice, 355.
} 


\section{2. Șulh in Qiṣāṣ and Diyat}

Qișāṣ means to punish the offender in like-manner as he has caused to the victim. Qișās is an offence related to murder and causing bodily injury. The punishment of qișās is fixed by law which is retaliation or diyat (compensation or blood money), but can be remitted by the victim and the victim's heirs. ${ }^{31}$ The victim's heirs have the right of qișās since qișās involves the rights of individuals. The victim's heirs have three options in resolving murder cases and cases related to bodily injury, i.e. to take qiṣaș from the convict, to pardon the offender, or to take diyat (compensation). ${ }^{32}$

Sulh is also applicable in qișās and diyat which involve offences of murder and bodily injury. Imam Mālik classified murder cases into two categories, i.e. wilful murder and murder by mistake. Imam Abū Hanifa, Imam Aḥmad and Imam al-Shāfi' $\overline{1}$ added another category of murder; that is quasi-wilful murder. ${ }^{33}$

\section{a) Șulh in Murder}

Punishment for wilful murder is qișạs or retaliation as mentioned in the Quran, ${ }^{34}$ however, Islam allows the heirs of the victim to remit the punishment of qișạs by pardoning the offender with or without compensation as stated in the Quran. ${ }^{35}$

Imam Malik agreed that though the heirs of the victim may forgive the offender, whether with diyat or without diyat, the offender is still subject to penal punishment. Penal punishment is punishment determined by the ruler ranging from the lightest to the most severe. Imam Ahmad, Imam Abū Hanifa and Imam al-Shāfi' $\overline{1}$ differ with Imam Mālik and opine that since the heirs of the victim have forgiven the offender, penal punishment is not necessary. ${ }^{36}$ The

\footnotetext{
31 Shabbir, M., Outlines of Criminal Law and Justice in Islam, 192.

32 Abū Dawūd, Sunan Abū Dāwūd, Kitab al-Diyat, vol. 5, hadith no. 4578.

33 Al-Khin, M., al-Bugho, M., \& Ash Sharbaji, A., al-Fiqh al-Manhajī 'ala Madhhab al-Imām al-Shāfi ‘̀: Kitab Fikah Mazhab Syafie (Kuala Lumpur: Pustaka Salam, 2010), 1779.

34 Surah al-Baqarah, 2: 178.

35 Surah al-Baqarah, 2: 178.

36 Syed, M.H., Crime and Punishment under Islamic Law (India: Anmol Publications Pvt. Ltd, 2008), 198.
} 
Shafi'i hold that liability to pay diyat for wilful murder is on the offender by using the offender's property himself. ${ }^{37}$

There is no conflicting view on șulh in qiṣas involving wilful murder. Islamic law gives privilege to the victim's heirs to decide for punishment to the offender, either by continuing with the original punishment of murder (retaliation) or to resolve the case by way of sulh. According to Imam alShāfi' 1 the victim's heirs also have the right to withdraw the whole amount of diyat or a partial amount of diyat. ${ }^{38}$

Quasi-wilful murder is a situation where the offender injures a victim resulting in the latter's death unintentionally. In other words, the offender has the intention to cause injury to the victim with no intention to kill him. For instance, the offender beats the victim with a light stick, or small stone, causing the victim to die. The punishment for quasi-wilful murder is diyat as reported by al-Mughira b. Shu'ba that a woman killed her fellow-wife with a tent-pole. The Prophet SAW ordered the relative of the offender on the father's side to pay diyat for the victim (the wife and the unborn child).$^{39}$ Imam Abu Hanifa, Imam Ahmad and Imam al-Shāfi' $\overline{1}$ agree that the punishment for quasi-wilful murder is diyat only or a combination of diyat and ta ' $z i r^{40}$ The offender is not subjected to qișās. The al-Shāfi' $\overline{1}$ opines that diyat for quasi-wilful murder is paid using the property of the 'aqilah. ${ }^{41}$

Murder by mistake is a situation where the offender unintentionally kills the victim by accident. As stated in the Quran, ${ }^{42}$ the punishment for murder by mistake is to free a Muslim slave and to pay diyat to the victim's heirs. If the offender is unable to find a slave to free, he has to fast two consecutive months. Imam Abū Hanifa, Imam Aḥmad, Imam Mālik and Imam al-Shāfi ‘̄ agree that the punishment for murder by mistake can be a combination of diyat and $t a{ }^{\prime} z \bar{i} r .{ }^{43}$ The al-Shāfi' $\overline{1}$ also agrees that diyat for unintentional murder is paid using the property of the 'aqülah. According to Imam Mālik, Imam al-

37 Al-Khin, M., al-Bugho, M., \& Ash Sharbaji, A., al-Fiqh al-Manhajī 'ala Madhhab al-Imām al-Shāfi 'ĩ: Kitab Fikah Mazhab Syafie, 1811.

38 Al-Khin, M., al-Bugho, M., \& Ash Sharbaji, A., al-Fiqh al-Manhajī 'ala Madhhab al-Imām al-Shāfi 'ĩ: Kitab Fikah Mazhab Syafie, 1779.

39 Imam Muslim, Șah̄in Muslim, Oaths Muharibin, Retaliation and Blood Money, book 16, hadith no. 4171.

40 Syed, M.H., Crime and Punishment under Islamic Law, 199.

41 Al-Khin, M., al-Bugho, M., \& Ash Sharbaji, A., al-Fiqh al-Manhajī 'ala Madhhab al-Imām al-Shāfi ‘̄: Kitab Fikah Mazhab Syafie, 1811.

42 Surah al-Nisā', 4: 92.

43 Syed, M.H., Crime and Punishment under Islamic Law, 200. 
Shāfi' $\overline{1}$ and Imam Aḥmad 'aqīlah means the agnatic male relatives on paternal side such as brothers, nephews, uncles and cousins. Imam Abū Hanifa defines 'aqülah as an institution or organization from which a person receives support or help such as bank, ministry and army. If a person does not belong to any institution or organization, his 'aqīlah is his paternal relative. If the 'aqilah is unable to pay the diyat, the government will pay the diyat. ${ }^{44}$ Nevertheless, if the victims' legal heirs have forgiven the offender and agree to remit freely without accepting diyat, it amounts to șulh.

If the offender of unintentional murder or murder by mistake has been forgiven by the heirs, the offender will not be liable for diyat, but can be subjected to $t a{ }^{\prime} z \bar{i} r$. Ta ' $z \bar{i} r$ aims to prevent the criminal from repeating offences in the future. $T a$ ' $z \bar{\imath} r$ can be imposed for crimes against Allah or individuals. There are certain offences that have been mentioned in the Quran without specific punishment and therefore left to the authority to decide. ${ }^{45}$

\section{b) Șulh in Bodily Injury}

Qiṣās for bodily injury means imposing a punishment which is like the offence imposed on the victim. ${ }^{46}$ The victim of bodily injury has two options in this respect, either to punish the offender with retaliation (qișass) or forgive the offender and receive compensation through the process of șulh.

Al-Shāfi' 1 emphasise that the victim's heirs have the right to withdraw the whole amount of diyat or a certain amount of diyat. ${ }^{47}$ Sulh in diyat is not allowed if the heirs demand the amount of diyat more than specified in Islamic law. This amounts to riba or interest. All Muslim jurists agree that the implementation of șulh in qișāṣ is allowed either with the full amount of diyat or part of the diyat. ${ }^{48}$ Diyat is a punishment for unintentional murder or murder by mistake. However, it does not deny the right of the ruler to impose a suitable $t a$ ' $z \bar{\imath} r$ punishment if public interests necessitates it. ${ }^{49}$

\footnotetext{
44 Anwarullah, The Criminal Law of Islam, 104.

45 Hakeem, F., Haberfeld, M.R. \& Verma, A., Policing Muslim Communities: Comparative International Context (New York: Springer, 2012), 16.

46 Anwarullah, The Criminal Law of Islam, 104.

47 Al-Khin, M., al-Bugho, M. \& Ash Sharbaji, A., al-Fiqh al-Manhajī 'ala Madhhab al-Imām al-Shāfi 'ĩ: Kitab Fikah Mazhab Syafie, 1779.

48 'Awdah A.Q., al-Tashri' al-Jinā' $\bar{\imath}$ al-Islāmī (Karachi: International Islamic Publishers, 1987), 167.

49 Hakeem, F., Haberfeld, M.R. \& Verma, A., Policing Muslim Communities: Comparative International Context, 16.
} 


\section{Sulh in $\mathrm{Ta}^{6} z \bar{i} r$}

Sulh in $t a ' z \bar{v} r$ is applicable in any of the ta' $z \bar{v} r$ crimes, whether the offence involved the rights of Allah SWT or the rights of the individual. In a ta 'zi $\bar{r}$ offence, the ruler has the discretion to determine the kind of sentence to the offender. It is considered as sulh if the ruler has pardoned the accused and reduced the punishment on him provided that the offence involves public interests. In case the offence merely infringes individuals' rights, whether the court imposes a lenient sentence to the accused depends on the forgiveness of the victim..$^{50}$

\section{FORGIVENESS IN ȘULH}

Forgiveness is not an element of șulh, but plays an integral part in șulh. Not all cases can be withdrawn with forgiveness as it depends on type of offences committed and when forgiveness is given. The criminal case that has infringed the right of individuals may be withdrawn if the victim has forgiven the accused. The court cannot simply pardon the accused if the offence has infringed the right of individuals. Nevertheless, in cases that involve the right of Allah, the court may pardon the accused and substitutes with a lesser punishment.

Certain $h u d \bar{u} d$ cases which particularly involve the rights of individuals can be withdrawn with forgiveness provided that the matter has not been brought to the authority. Imam Abū Hanifa opines that hudūd cannot be forgiven by the accused or pardoned by the ruler if the matter has been brought to the authority. He gives an example, if the Ruler orders to cut off the hand of the thief, but the victim has forgiven the thief, the forgiveness is battil (falsehood). Al-Shāfi'i decides that $h u d \bar{u} d$ can be waived after repentance or pardon in false accusation and robbery if the matters have not been brought before the authority, and the accused has been forgiven by the victim.

In cases of false accusation, Imam Abū Ḥanifah, Imam Shāfi ‘̄̄, Imam Mālik, and Imam Hanbali agree that if the victim does not wish to lodge a complaint against the accused and has forgiven the criminal act of the accused, the hadd punishment will not be imposed. ${ }^{51}$ As in the cases of theft and robbery, there is a hadith reported by 'Abd Allāh ibn Mas'ud, where there a man committed theft and it was ordered that his hand be cut off. The Prophet SAW said nothing could prevent him from executing the punishment if the case has been brought

50 Mehdi, R., The Islamization of the Law in Pakistan (United Kingdom: Routledge, 2013), 109.

51 Shabbir,M., Outlines of Criminal Law and Justice in Islam, 172-173. 
to the ruler. The Prophet SAW further said that Allah loves forgiveness. ${ }^{52}$ This hadith indicates that if the victim has forgiven and compromised with the offender before the matter is brought to the ruler, hudiud will be withdrawn. As in the case of robbery, if the victim has forgiven the accused before the matter is brought to court, the punishment may be withdrawn against the accused. However, the accused may be liable to the victim or the victim's heirs if the act he had committed caused death, or injury to the victim. As such, the accused has to face qiṣās punishment or diyat unless he has been forgiven by the victim.

Forgiveness from the victim is highly recommended in qișās cases. It can be seen in the hadith reported by Anas ibn Mālik that he noticed that the Prophet SAW, whenever a dispute that involved qișās was brought before him, he would exhort the aggrieved party to pardon the offender. ${ }^{53}$ In another hadith Aishah reported that the Prophet said:

"The disputants should refrain from taking retaliation. The one who is nearer should forgive first and then the one who is next to him, even if the one who is forgiven is a woman." 54

Islam allows the heirs of the victim to remit the punishment of qișās by pardoning the offender with or without compensation as stated in the alQuran. ${ }^{55}$ Imam Mālik agrees that though the heirs of the victim have forgiven the offender, whether with diyat or without diyat, the offender is subjected to penal punishment. Penal punishment is punishment determined by the ruler ranging from the lightest to the most severe. Imam Mālik, Imam Abū Hanifa and Imam al-Shāfi ‘ $\overline{1}$ differ with Imam Ahmad and opine that since the heirs of the victim have forgiven the offender, penal punishment is not necessary. ${ }^{56}$

Though qiṣās is withdrawn the offender must pay diyat to the victim's heirs unless there is forgiveness. The heirs of the victim when forgiving have options, either to demand compensation against the offender or not. ${ }^{57}$ According to Imam al-Shāfi' 1 the victim's heirs also have the right to withdrawn the whole amount of diyat or partial amount of diyat. ${ }^{58}$ In case the victim's heirs have

\footnotetext{
Musnad Ahmad, hadith no. 4157.

53 Sunan Abū Dāwūd, hadith no. 4495.

54 Sunan $A b \bar{u} D \bar{a} w \bar{u} d$, hadith no. 4523

55 Surah al-Baqarah, 2: 178.

56 Syed, M.H., Crime and Punishment under Islamic Law, 198.

57 Anwarullah, The Criminal Law of Islam, 80.

58 Al-Khin, M., al-Bugho, M., \& Ash Sharbaji, A., al-Fiqh al-Manhajī 'ala Madhhab al-Imām al-Shāfi 'ĩ: Kitab Fikah Mazhab Syafie, 1779.
} 
forgiven the offender, but refuse to demand diyat, kaffarah (to free a Muslim slave or fasting two months consecutively) may be imposed on the offender.

In the case of bodily injury, qișās punishment may be remitted if the victim has forgiven the offender. If the offender has been forgiven by the victim, Allah SWT will pardon the offender and reward the victim. ${ }^{59}$ According to Imam Abu Hanifa and Imam Mālik, if the victim or victim's heir forgives the offender and demands compensation, it is considered as sulh.

Forgiveness can withdraw ta 'zìr punishment. If a $t a{ }^{\prime} z \bar{l} r$ offence involves the rights of Allah and public interests, the ruler has the power to pardon the offender and the $t a$ ' $z \bar{l} r$ punishment can be withdrawn. But, in case the offence has violated the rights of individuals, if the victim refuses to forgive the offender, the $t a{ }^{\prime} z \bar{i} r$ punishment shall be inflicted upon him. As held by Imam Abū Hanifa, if the ta' $z \bar{r} r$ offence violates the rights of individuals, a ta 'zir punishment shall be imposed because the judge has no right to withdraw the right of the individual unless the victim has forgiven the offender. If the $t a ' z \bar{l} r$ violates the rights of Allah, it depends on the discretion of the judge. If the ta'zir brings about mașlahah (benefit) to the public at large, then a ta' $z \bar{\imath} r$ punishment shall be imposed. Otherwise, if a ta'zir punishment does not bring any benefit and the offender repents, the judge may dismiss the case. Imam Shāfi' $\overline{1}$ agrees that $t a ' z \bar{\imath} r$ involving right of individuals can be forgiven, reconciled, and dismissed. ${ }^{60}$ Though the victim has forgiven the offender, the ruler may punish the offender with a $t a$ ' $z \bar{\imath} r$ if the offence has affected public interests. $^{61}$

\section{SQULH UNDER THE PAKISTAN CRIMINAL LAW}

\section{1. Șulḥ in Qiṣāṣ and Diyat}

The current Pakistan Penal Code allows offences of murder and injury to be resolved by way of compromise or șulh before the execution of a qișās punishment. Injury and murder are compoundable offences which can be resolved between the parties without pursuing court procedure. The offences

59 Please refer Surah al-Nisa' verse 148 to the end of Surah al-An'am; Rahman, S.S., Tafsir Ibn Kathir (abridged), vol. 3 (Riyāḍ: Darussalam, 2003), 190-191.

60 Al-Zuhaili, W., Fiqh \& Perundangan Islam, 220.

61 Nasimah Hussin, 'Discretionary Punishment in Islamic Law with Special Reference to the Sharī'ah Courts of Malaysia', (Ph.D thesis, University of Edinburgh, 1997), 167-168. 
can be compounded by a guardian if the victim or the legal heirs are under the age of eighteen years or are mentally ill. If the accused has been convicted and an appeal is pending, the offence can be compounded with the leave of the High Court. In case the offence has been compounded, the accused is acquitted.

\section{a) Murder}

Under the Pakistan Penal Code, punishment for intentionally causing death is death as qișās or imprisonment for life or up to twenty five years as a ta 'zīr if qișās is not applicable. However, qișās for intentionally causing death will not be enforced if the wali (guardian of the deceased) voluntarily waives the right of qișās with or without compensation or compound his right of qișās. The court shall take down the statement of the wali on oath and record an opinion that clearly states that the waiver of qișạs was voluntary. The state cannot simply give pardon to the offender without permission by the victim.

The wali may compound his right of qișās for intentionally causing death upon accepting badl al-șulh. Badl al-șulh is a mutually agreed compensation according to the Shariah to be paid or given by the offender in kind or in the form of movable or immovable property. The payment of badl al-sulh can be made on demand or on a deferred date as agreed between the offender and the walì. In case the wali does not waive or compound his right of qișās for intentionally causing death, the court shall punish the offender with death as qiṣa $\bar{a}$ or imprisonment of life, or imprisonment of up to fourteen years as $t a$ ' $z \bar{v}$ r.

An illustration of șulh in murder can be seen in Muhammad Yousuf v. The State and Another, ${ }^{62}$ where all the legal heirs of the deceased had pardoned the accused and waived their right of qișās and diyat against them and had no objection on the acquittal. The Sessions Court concluded that the compromise between the parties was genuine and voluntary and there was no other legal bar in the acceptance of the same. On appeal, the appellate court considering the case had reached a compromise between the parties and proceeded to decide the murder case. The court allowed the appeal on the judgment of conviction and the sentence was set aside and the offender was acquitted of the charge.

In Shafi Muhammad and Another v. The State and Another, ${ }^{63}$ the accused was convicted for the offence of murder and sentenced to death and compensation payable to the legal heirs of the deceased. The appellant appealed the conviction and the sentence. During pendency of the appeal,

\footnotetext{
62 Muhammad Yousuf v. The State and another [2010] PCr. LJ 500.

63 Shafi Muhammad and another v. The State and another [2010] PCr. LJ 634.
} 
the accused was pleading for an acquittal on the grounds that the heirs of the deceased had compromised with the accused before the Sessions Court and it had been recorded by the court. The court was satisfied that all legal heirs had compromised voluntarily without any coercion and pardoned the accused in the name of Allah. The accused shows his repentance when he appeared before the court and he had sought forgiveness from Allah. The Court accepted the appeal. The Court observed that since the 'afw (pardon) was granted by the legal heirs, the compromise was accepted. The conviction of murder and sentence of death were thus set aside and the accused was acquitted.

Compromise is allowed if all legal heirs of the victim have pardoned the accused and intended to compromise. In Zulfiqar v. The State, ${ }^{64}$ the accused was convicted for the offence of murder of his brother under section 308 of the Pakistan Penal Code. The accused shot the deceased with the motive of obtaining more land in his inheritance. The father of the accused forgave him. The Sessions Court held the accused to pay diyat and imprisonment of up to fourteen years as $t a$ ' $z \bar{\imath} r$ under section 308(2) of the Pakistan Penal Code. The case was brought to appeal by the accused's and the deceased's mother, to enhance his sentence. The defence counsel argued that since the father had forgiven the accused, he could not be convicted for murder and should be acquitted. The court held that the appeal and the revision was dismissed. It is a case of partial compromise since the father had forgiven the accused, but the mother as another legal heir of the deceased had not. The court observed that the Sessions Court judge has decided the maximum sentence as provided under section 308(2) of the Pakistan Penal Code. The court maintain the decision and the sentence was awarded by the Sessions Court.

However, compromise is not allowed if a death sentence if awarded as ta 'zir. For example, in Niaz Ahmad v. The State $P L D^{65}$ where the accused was charged with murder. The Sessions Court had convicted the accused for the offence of murder and had sentenced him to death under $t a$ ' $z \bar{r} r$ and a fine. The accused filed an appeal on the judgment to the High Court. In the appeal, the deceased's husband had compromised with the accused and this was considered as a mitigating factor. The court dismissed the appeal and observed that the compromise was only applicable where the sentence of death is awarded as qișās, not where death sentence is awarded as ta 'zìr.

64 Zulfiqar v. The State [2006] PCr. LJ 1559.

65 Niaz Ahmad v. The State PLD [2003] SC 635. 


\section{b) Hurt}

The Penal Code provides that punishment for intentionally causing injury is qișa $\bar{s}$ and if qișas is not applicable, the offender shall be liable to arsh (compensation for causing injury to be paid to the victim or his heirs) or imprisonment as $t a^{\prime} z \bar{l} r$. However, qișās for injury shall not be enforced if the victim waives his right of qișās or compounds the offence with badl al-șulh. If the right of qișa ș for injury has been waived or compounded, the court may acquit or award $t a ' z \bar{\imath} r$ to the offender.

As illustrated in Falak Sher v. State ${ }^{66}$ the accused was charged for murder, causing injury and attempted robbery. The accused was convicted by the Sessions Court for the offences charged. The Sessions Court held that the accused pay a certain amount of fine, imprisonment as $t a$ ' $z \bar{i} r$ and the death sentence with compensation. The entire sentence would run concurrently. While the court sought confirmation for the death sentence, the accused filed an appeal seeking his acquittal on the basis of a compromise reached between the parties which was supported by a genuine report. The court observed that the legal heirs of the deceased were his real father and his real mother. The deceased's three siblings were injured during the incident and the two of them suffered minor injuries. The parents of the deceased made statements that in the name of Allah, they had forgiven all accused without receiving any badl al-șulh and waived their right of qișās and diyat, having no objection if the accused is acquitted on the basis of compromise. The siblings of the deceased who suffered injury also had pardoned the accused. The appellate court ordered that since the parents of the deceased waived the right of qișas and diyat, they have waived their right of daman. Since the family of the deceased had compromised, the charge of murder and causing injury were ceased but the court maintained the conviction of attempted robbery.

Section 337 of the Code of Criminal Procedure allows the Magistrate Court to acquit the offender in cases of murder and injury with the permission of the victim and their legal heirs. The court has to record the reasons for acquitting and furnish a copy of the record to the offender. The offender shall be examined as a witness in the subsequent trial. The High Court may also order the Magistrate Court to acquit the offender with permission of the victim or the legal heirs in case of hurt and murder.

66 Falak Sher v. State [2011] PCr. LJ 713. 


\section{2. Șulh in Theft and Robbery}

Under the Offences against Property (Enforcement of Hudud) Ordinance punishment for theft is hudūd if the offender had fulfilled all the elements of theft in hudīd i.e. the offender is an adult, believes that the victim does not know about his act of theft, the stolen property reaches the value of nișab and the property is not already stolen property. However, section 11 (c) of the Ordinance provides that hadd shall not be enforced if the victim withdraws his allegation of theft before the execution of hadd, although the court may award ta' $z \bar{r} r$. This section implies the possibility for the offender and the victim to compromise before the court executes punishment. The court, instead of punishing the offender with hadd, may punish the offender with ta 'zìr based on the Pakistan Penal Code 1860.

This exception of hadd is also applicable in a robbery in which, if the victim withdraws allegation against the offender before the execution of hadd, the court may award ta'zīr under the Pakistan Penal Code 1860. The punishment of $t a$ ' $z \bar{i} r$ for robbery is imprisonment no less than three years and no more than ten years, and shall be liable to a fine; and, if the robbery is committed on the highway the imprisonment may be extended to fourteen years with fine.

It can be seen that Pakistan allows sulh to be practiced in the case of murder, injury, theft, and robbery provided that the victim has forgiven the accused and both parties agreed to compromise. In case of murder and injury, instead of punishing the offender with the punishment prescribed in the Penal Code, the victim or the legal heirs may forgive, reconcile, and claim compensation from the offender. If the court is satisfied that reconciliation is done voluntarily, the court may impose ta' $z \bar{\imath} r$ on the offender. In the offence of theft and injury, hudūd punishment can be remitted if the victim has forgiven the offender before the execution of the punishment and the offender shall be punished with $t a$ ' $z \bar{\imath} r$.

\section{CONCLUSION}

It is submitted that Islam encourages șulh as a resolution of criminal disputes, but it is only applicable in certain offences which involves individuals' rights such as in the offence of murder, causing injury, theft, false accusation, and robbery. Sulh gives an opportunity for the offender to reconcile and to be forgiven by the victim. Through sulh, the offender is subjected to lesser punishment instead of the original punishment which is more severe. Nevertheless, it requires the consent or approval of the victim or the victim's heirs before resolving the 
criminal case by way of șulh. Sulh can only be applied if the victim is willing to forgive the accused and both parties agree to compromise and reconcile. Sulh is not to about allowing the offender to escape from responsibility, but to provide opportunities for the offender to restore what has been taken from the victim. Though the offender is not punished with the original punishment, they will be liable for restitution, to pay compensation to the victim or the victim's heirs, and even be punished with ta 'zir punishment.

Pakistan has since has implemented the Islamic criminal law, allowing șulh to be applied in resolving certain criminal cases. It can be seen in the case of murder and bodily injury, where sulh is allowed even though case has been brought to the court provided that the punishment has not been executed. If the court is satisfied that the offender and the victim agree to compromise, and the victim has forgiven the accused, the allegation against the offender is removed and the offender acquitted. In the cases of false accusations, theft, and robbery, it is considered as sulh when the victim forgives the accused and withdraws the allegation before the case is brought to court. However, this does not prevent the authority to punish the offender with $t a$ ' $z \bar{\imath} r$ punishment as a lesson to others. Pakistan has proven that sulh can be implemented and still be relevant for practised today. It is suggested that șulh should be allowed to resolve the offences of false accusation, theft, robbery, murder and causing injury if the victim has forgiven the accused and the victim as well as the offender agree to compromise, as allowed in Islam.

\section{REFERENCES}

'Awdah A.Q., al-Tashri' al-Jinā'̄o al-Islāmī (Karachi: International Islamic Publishers, 1987).

Al-Khin, M., al-Bugho, M., \& Ash Sharbaji, A., al-Fiqh al-Manhajī 'alā Madhhab al-Imām al-Shāfi'i: Kitab Fikah Mazhab Syafie (Kuala Lumpur: Pustaka Salam, 2010).

Al-Zuhaili, W., Figh \& Perundangan Islam, vol. 6, trans. Ahmad Shahbari Salamon (Kuala Lumpur: Dewan Bahasa dan Pustaka, 2006).

Anwarullah, The Criminal Law of Islam (Kuala Lumpur: A.S. Noordeen, 2008).

Al-Bukhari, Șahịh Bukhārī, Book of Peacemaking, chapter 49, vol. 3, hadith no. 856 and 866 .

Hakeem, F., Haberfeld, M.R. \& Verma, A., Policing Muslim Communities: Comparative International Context (New York: Springer, 2012).

Hashim Mehat, Malaysian Law \& Islamic Law on Sentencing (University of Michigan: International Law Book Services, 1991). 
Hussain, S.S., Islam and Human Rights (Selangor: Budaya Ilmu, 1991).

Islam, M. Z., 'Provision of Alternative Dispute Resolution Process in Islam,' Journal of Business and Management, 6/3 (2012).

Mahmood, T., et al., Criminal Law in Islam and the Muslim World: A Comparative Perspective (New Delhi: Institute of Objective Studies, 1996).

Marghinani, S.B., The Hedaya: Commentary on the Islamic Laws, trans. Charles Hamilton (New Delhi: Kitab Bhavan, 1985).

Mehdi, R., The Islamization of the Law in Pakistan (United Kingdom: Routledge, 2013).

Mohammad Tahir Haji Mohammad, Rights and Duties in Shari'ah and Common Law (Selangor: Ilmiah Publishers, 2003).

Muhammad Bakar Ismail, al-Fiqh al-Wädih: Fiqh Lengkap, vol. 2, trans. M. Yusuf Sinaga et al. (Selangor: Jasmine Enterprise, 2008).

Muhammad, I., al-Ṣulh ka al-Sabab li Inqid̄a ’i al-Da 'wā al-Jinā'iyah (Egypt: Dār al-Jamī'ah al-Jadīdah, 2011).

Al-Muwatta of Imam Malik Ibn Anas, Book 41, The First Formulation of Islamic Law, trans. Aisha Abdurrahman Bewley (USA: Routledge, 2010), 350.

Nasimah Hussin, 'Discretionary Punishment in Islamic Law with Special Reference to the Sharī'ah Courts of Malaysia,' (Ph.D. thesis, University of Edinburgh, 1997).

Nasimah Hussin, 'Mediation in Islamic Criminal Law', in Mediation in Malaysia: The Law and Practice (Selangor: Lexis Nexis, 2010).

Rahman, S.S., Tafsir Ibn Kathir (abridged), vol. 3 (Riyāḍ: Darussalam, 2003).

Raihanah Azahari, Sulh dalam Kes Kekeluargaan Islam (Kuala Lumpur: Penerbit Universiti Malaya, 2008).

Shabbir, M., Outlines of Criminal Law and Justice in Islam (United Kingdom: Edward Elgar Publishing, 2013).

Syed, M.H., Crime and Punishment under Islamic Law (India: Anmol Publications Pvt. Ltd., 2008).

\section{Cases}

Falak Sher v. State [2011] PCr. LJ 713.

Muhammad Yousuf v. The State and another [2010] PCr. LJ 500.

Niaz Ahmad v. The State PLD [2003] SC 635. 
Jurnal Syariah, Jil. 24, Bil. 1 (2016) 115-136

Shafi Muhammad and another v. The State and another [2010] PCr. LJ 634. Zulfiqar v. The State [2006] PCr. LJ 1559. 